\title{
4-Hydroxyphenylacetic acid oxidation in sulfate and real olive oil mill wastewater by electrochemical advanced processes with a boron-doped diamond anode
}

\author{
Nelly Flores, Pere Lluís Cabot, Francesc Centellas, José Antonio Garrido, Rosa María Rodríguez, Enric Brillas *, \\ Ignasi Sirés*
}

Laboratori d'Electroquímica dels Materials i del Medi Ambient, Departament de Química Física, Facultat de Química, Universitat de Barcelona, Martí i Franquès 1-11, 08028 Barcelona, Spain

\section{A R T I C L E I N F O}

\section{Article history:}

Received 3 August 2016

Received in revised form 22 September 2016

Accepted 23 September 2016

Available online xxx

Keywords:

BDD anode

Electro-Fenton

4-Hydroxyphenylacetic acid

Olive oil mill wastewater

Photoelectro-Fenton

\begin{abstract}
A B S T R A C T
The degradation of 4-hydroxyphenylacetic acid, a ubiquitous component of olive oil mill wastewater (OOMW), has been studied by anodic oxidation with electrogenerated $\mathrm{H}_{2} \mathrm{O}_{2}\left(\mathrm{AO}-\mathrm{H}_{2} \mathrm{O}_{2}\right)$, electro-Fenton (EF) and photoelectro-Fenton (PEF). Experiments were performed in either a $0.050 \mathrm{M} \mathrm{Na}_{2} \mathrm{SO}_{4}$ solution or in real OOMW at pH 3.0, using a cell with a boron-doped diamond (BDD) anode and an air-diffusion cathode for $\mathrm{H}_{2} \mathrm{O}_{2}$ generation. Hydroxyl radicals formed at the BDD surface from water oxidation in all processes and/or in the bulk from Fenton's reaction between added Fe ${ }^{2+}$ and generated $\mathrm{H}_{2} \mathrm{O}_{2}$ in EF and PEF were the main oxidants. In both matrices, the oxidation ability of the processes increased in the order AO- $\mathrm{H}_{2} \mathrm{O}_{2}<\mathrm{EF}<\mathrm{PEF}$. The superiority of PEF was due to the photolytic action of UVA radiation on photosensitive by-products, as deduced from the quick removal of Fe(III)-oxalate complexes. The effect of current density and organic content on the performance of all treatments was examined. 4-Hydroxyphenylacetic acid decay obeyed a pseudo-first-order kinetics. The PEF treatment of $1.03 \mathrm{mM}$ 4-hydroxyphenylacetic acid in $0.050 \mathrm{M} \mathrm{Na}_{2} \mathrm{SO}_{4}$ allowed $98 \%$ mineralization at $360 \mathrm{~min}$ even at low current density, whereas $80 \%$ mineralization and a significant enhancement of biodegradability were achieved with the real OOMW.
\end{abstract}

C 2016 Published by Elsevier Ltd.

\section{Introduction}

The olive oil produced in Spain and other Mediterranean countries accounts for more than $75 \%$ of total world production. This, in turn, entails a huge annual release of industrial olive oil mill wastewater (OOMW). These effluents are usually acidic and extremely hazardous for the aquatic environment due to their very large organic matter contents and high turbidity levels, which cause a poor oxygenation and light penetration $[1,2]$. OOMW mainly contains phenols, acids, lipids, sugars and tannins $[3,4]$. A limited number of works have described the treatment of these effluents by catalytic wet air oxidation [5] and electrolysis with a Pt anode [6,7], showing a significant destruction of phenolic components. More research efforts are then needed to degrade OOMW and its main single components to devise an optimum integral treatment for such industrial wastewater.

4-Hydroxyphenylacetic acid is a typical phenolic component routinely found in OOMW. It is a primary product formed upon oxidation of tyrosol (4-hydroxyphenylethanol), which is a well known phenolic compound in OOMW as well [8,9]. On the other hand, 4-hydroxyphenylacetic acid is useful for the industrial synthesis of various end products like the $\beta$-blocker atenolol, among others. However, the information on its degradation routes and fate in the field of

\footnotetext{
* Corresponding author.

Email addresses: brillas@ub.edu (E. Brillas); i.sires@ub.edu, isiresa@gmail.com (I. Sirés)
}

wastewater treatment is scarce. The removal of 4-hydroxyphenylacetic acid by advanced oxidation processes (AOPs) like zero-valent iron [10] and $\mathrm{UV} / \mathrm{H}_{2} \mathrm{O}_{2}$ and Fenton's reagent [11] has been reported. Conversely, as far as we know, its destruction by powerful electrochemical AOPs (EAOPs) has not been reported yet

Over the last fifteen years, the EAOPs have received increasing attention to remove toxic and/or non-biodegradable organic pollutants from wastewater [12-15]. These methods are particularly viable owing to their environmental compatibility, high energy efficiency, versatility, amenability of automation, safe operation under mild conditions and easy scale-up. The great oxidation power of EAOPs is based on the continuous in situ generation of reactive oxygen species (ROS) like hydroxyl radical $\left({ }^{\circ} \mathrm{OH}\right)$, the second strongest oxidant known after fluorine. A high standard reduction potential $\left(E^{\circ}\left(\bullet \mathrm{OH} / \mathrm{H}_{2} \mathrm{O}\right)=2.80 \mathrm{~V} /\right.$ SHE) explains its ability to non-selectively react with most organics up to mineralization to $\mathrm{CO}_{2}$, water and inorganic ions $[13,14]$.

The boron-doped diamond (BDD) thin-film anodes yield the quickest mineralization of organics in the EAOPs. This anode possesses larger oxidation ability than conventional $\mathrm{Pt}$ [16-18] and $\mathrm{PbO}_{2}$ [19] ones as a result of the low adsorption of both, ${ }^{\bullet} \mathrm{OH}$ formed at its surface and organics, as well as its greater $\mathrm{O}_{2}$-evolution overvoltage. These properties allow the mineralization of aromatics [12,20-27] and by-products like short-chain linear carboxylic acids [28]. The oxidation ability of EAOPs may be upgraded when $\mathrm{H}_{2} \mathrm{O}_{2}$ is continuously generated at the cathode from the two-electron reduction of $\mathrm{O}_{2}$, 
as follows $[13,14]$ :

$$
\mathrm{O}_{2}+2 \mathrm{H}^{+}+2 \mathrm{e}^{-} \rightarrow \mathrm{H}_{2} \mathrm{O}_{2}
$$

Anodic oxidation with electrogenerated $\mathrm{H}_{2} \mathrm{O}_{2}\left(\mathrm{AO}-\mathrm{H}_{2} \mathrm{O}_{2}\right)$, electro-Fenton (EF) and photoelectro-Fenton (PEF) are the most important EAOPs based on $\mathrm{H}_{2} \mathrm{O}_{2}$ electrogeneration. They use effective carbonaceous cathodes for Reaction (1) like BDD [29], activated carbon fiber [30], carbon nanotubes [31], carbon sponge [32], carbon felt $[9,24,33-35]$ and carbon-polytetrafluoroethylene (PTFE) gas-diffusion devices [27,36-39].

This paper presents a study on the oxidation of 4-hydroxyphenylacetic acid, spiked in either synthetic sulfate solutions with ultrapure water or real OOMW solutions, by $\mathrm{AO}-\mathrm{H}_{2} \mathrm{O}_{2}, \mathrm{EF}$ and PEF using a $\mathrm{BDD} /$ air-diffusion tank reactor. Very worth mentioning, no previous studies have addressed the treatment of real OOMW by EAOPs with an air-diffusion cathode, which is mandatory aiming to scale-up these promising technologies. The effect of current density $(j)$ and substrate content on the degradation rate and mineralization current efficiency (MEC) was examined. The kinetics for the substrate decay and the evolution of generated carboxylic acids were monitored by high-performance liquid chromatography (HPLC). The change in biodegradability was determined during the treatment of OOMW. Gas chromatography-mass spectrometry (GC-MS) was used to identify the main organic components of the raw OOMW.

\section{Experimental}

\subsection{Chemicals}

4-Hydroxyphenylacetic acid (98\% purity) was purchased from Sigma-Aldrich. Analytical grade oxalic acid was supplied by Merck. Iron(II) sulfate heptahydrate and anhydrous sodium sulfate were of analytical grade supplied by Fluka. Analytical grade sulfuric acid from Acros Organics was used to adjust the initial $\mathrm{pH}$ to 3.0. Aqueous solutions were prepared with high purity water from a Millipore Milli-Q system (resistivity $>18 \mathrm{M} \Omega \mathrm{cm}$ at $25^{\circ} \mathrm{C}$ ). Other chemicals were of HPLC or analytical grade provided by Panreac and Merck.

\subsection{Real OOMW sample}

The real OOMW was obtained from a decanter receiving wastewater generated upon cleaning stages during the premium extra virgin olive oil production at a small size oil mill in northeastern Spain. It was collected in November of 2015 and kept at $4{ }^{\circ} \mathrm{C}$ before use. The treatments were made after filtration of the OOMW sample with an $18 \mu \mathrm{m}$ filter, spiking or not $1.03 \mathrm{mM}$ 4-hydroxyphenylacetic acid, without or with dilution with Milli-Q water.

\subsection{Electrolytic system}

All the trials were carried out with an open, undivided, cylindrical glass cell containing $100 \mathrm{~mL}$ solutions under vigorous stirring with a magnetic bar at $700 \mathrm{rpm}$. The cell was surrounded with a double jacket where thermostated water was recirculated at $35^{\circ} \mathrm{C}$. This was the maximum temperature that could be used avoiding significant solvent evaporation. A $3 \mathrm{~cm}^{2}$ BDD (deposited onto $p$-Si) electrode supplied by NeoCoat (La-Chaux-de-Fonds, Switzerland) was used as the anode and a $3 \mathrm{~cm}^{2}$ carbon-PTFE air-diffusion electrode supplied by E-TEK (Somerset, NJ, USA) as the cathode. The interelectrode gap was about $1 \mathrm{~cm}$. The cathode was mounted as reported elsewhere [27] and was fed with air pumped at $300 \mathrm{~mL} \mathrm{~min}^{-1}$ for continuous
$\mathrm{H}_{2} \mathrm{O}_{2}$ generation on site. The experiments were performed at constant $j$ provided by an EG\&G Princeton Applied Research 273A potentiostat-galvanostat. The surfaces of the anode and cathode were initially cleaned and activated, respectively, under polarization in $100 \mathrm{~mL}$ of $0.050 \mathrm{M} \mathrm{Na}_{2} \mathrm{SO}_{4}$ at $100 \mathrm{~mA} \mathrm{~cm}{ }^{-2}$ for $180 \mathrm{~min}$.

Solutions with $0.21-2.06 \mathrm{mM}$ 4-hydroxyphenylacetic acid and $0.050 \mathrm{M} \mathrm{Na}_{2} \mathrm{SO}_{4}$ at $\mathrm{pH} 3.0$ were comparatively treated by $\mathrm{AO}-\mathrm{H}_{2} \mathrm{O}_{2}$, $\mathrm{EF}$ and PEF at $j$ values between 16.7 and $100 \mathrm{~mA} \mathrm{~cm}^{-2}$. These EAOPs were also applied to degrade the filtrated OOMW sample at $\mathrm{pH} 3.0$, either raw or diluted with ultrapure water, in the absence and presence of $1.03 \mathrm{mM}$ 4-hydroxylphenylacetic acid. For EF and PEF, $0.50 \mathrm{mM}$ $\mathrm{Fe}^{2+}$ was added as Fenton's catalyst since it was found optimal for many organics degraded under similar conditions [36-39]. For PEF, a Philips TL/6W/08 fluorescent black light blue tube of $\lambda_{\max }=360 \mathrm{~nm}$ placed at $8 \mathrm{~cm}$ above the solution surface was used. The average power density of this lamp was $5 \mathrm{~W} \mathrm{~m}^{-2}$, as determined with a Kipp\&Zonen CUV 5 UV radiometer.

\subsection{Analytical methods}

The $\mathrm{pH}$ and conductance of synthetic sulfate solutions and real OOMW samples were measured with a Crison GLP 22 pH-meter and a Metrohm 644 conductometer, respectively. The turbidity was determined with a WTW TURB 55 IR turbidimeter. The chemical oxygen demand (COD) was measured with Hach Lange LCK014, LCK514 and LCK614 COD cuvette tests using a Hach DR 3900 UV-vis spectrophotometer. Other parameters of the OOMW were determined according to the Standard Methods [40]. The 5-day biochemical oxygen demand $\left(\mathrm{BOD}_{5}\right)$ was obtained following a respirometric method with a WTW Oxitop 12 system using seed from a municipal wastewater treatment plant (method $5210 \mathrm{D}$ ). Total solids (TS) and total suspended solids (TSS) were determined upon evaporation and drying to constant weight in an oven at $103-105^{\circ} \mathrm{C}$ (methods $2540 \mathrm{~B}$ and $\mathrm{C}$ ). Phenol index was obtained according to the 4-aminoantipyrine direct spectrophotometric method $5530 \mathrm{D}$. Oil and grease content was measured via the partition-gravimetric method $5520 \mathrm{~B}$. Anions concentration was obtained by ion chromatography with a Kontron 465 LC equipped with a Waters IC-PAK, $150 \mathrm{~mm} \times 4.6 \mathrm{~mm}$, anion-exchange column at $35^{\circ} \mathrm{C}$ and coupled with a Waters 432 conductivity detector. A mixture of boric acid, sodium gluconate, sodium tetraborate, acetonitrile, butanol and glycerine was eluted at $2.0 \mathrm{~mL} \mathrm{~min}^{-1}$ as the mobile phase. The cations content was found by inductively coupled plasma (ICP-OES) using an Optima 3200RL spectrometer.

For total organic carbon (TOC) determinations, $1 \mathrm{~mL}$ samples were withdrawn from treated solutions, filtered with $0.45 \mu \mathrm{m}$ Whatman PTFE filters and $50 \mu \mathrm{L}$ directly injected into a Shimadzu VCSN TOC analyzer. Reproducible values with $\pm 1 \%$ accuracy were found.

Assuming the following total mineralization for 4-hydroxyphenylacetic acid:

$$
\mathrm{C}_{8} \mathrm{H}_{8} \mathrm{O}_{3}+13 \mathrm{H}_{2} \mathrm{O} \rightarrow 8 \mathrm{CO}_{2}+34 \mathrm{H}^{+}+34 \mathrm{e}^{-}
$$

the mineralization current efficiency (MCE) for each trial was estimated as follows [41]:

$$
\operatorname{MCE}(\%)=\frac{n F V \Delta\left(\text { TOC }_{\exp }\right.}{4.32 \times 10^{7} m I t} \times 100
$$

where $n=34$ is the number of electrons of the mineralization process, $F$ is the Faraday constant $\left(96,487 \mathrm{C} \mathrm{mol}^{-1}\right), V$ is the solution volume (L), $\Delta(\mathrm{TOC})_{\exp }$ is the TOC decay $\left(\mathrm{mg} \mathrm{L}^{-1}\right), 4.32 \times 10^{7}$ is a conver- 
sion factor to homogenize units $\left(3600 \mathrm{~s} \mathrm{~h}^{-1} \times 12,000 \mathrm{mg} \mathrm{C} \mathrm{mol}^{-1}\right)$, $m=8$ is the number of carbon atoms of 4-hydroxyphenylacetic acid, $I$ is the current (A) and $t$ is the electrolysis time (h).

The 4-hydroxyphenylacetic acid abatement was followed by reversed-phase HPLC using a Waters $600 \mathrm{LC}$ fitted with a BDS Hypersil $\mathrm{C} 186 \mu \mathrm{m}, 250 \mathrm{~mm} \times 4.6 \mathrm{~mm}$, column at $35^{\circ} \mathrm{C}$ and coupled with a Waters 996 photodiode array detector set at $\lambda=277.0 \mathrm{~nm}$. The samples of EF and PEF were immediately diluted with acetonitrile to stop the degradation process and filtered prior to injection. Measurements were made by injecting $10 \mu \mathrm{L}$ aliquots into the LC and eluting an acetonitrile/water (60:40) mixture at $0.6 \mathrm{~mL} \mathrm{~min}^{-1}$ as mobile phase. The chromatograms exhibited a peak for the parent compound at retention time $\left(t_{\mathrm{r}}\right)$ of $5.0 \mathrm{~min}$. Final carboxylic acids were identified by ion-exclusion HPLC using the same LC fitted with a Bio-Rad Aminex $\mathrm{HPX} 87 \mathrm{H}, 300 \mathrm{~mm} \times 7.8 \mathrm{~mm}$, column at $35^{\circ} \mathrm{C}$ and the photodiode array detector set at $\lambda=210.0 \mathrm{~nm}$. Aliquots of $10 \mu \mathrm{L}$ were injected into the $\mathrm{LC}$ and the mobile phase was $4 \mathrm{mM} \mathrm{H}_{2} \mathrm{SO}_{4}$ at $0.6 \mathrm{~mL} \mathrm{~min}^{-1}$. The chromatograms displayed a peak related to oxalic acid at $t_{\mathrm{r}}=7.0 \mathrm{~min}$.

The organic components of the real OOMW sample after filtration were identified by GC-MS using a NIST05-MS library to interpret the mass spectra. Aliquots were lyophilized and the residue was dissolved in $1 \mathrm{~mL}$ of ethyl acetate. GC-MS analysis was performed on an Agilent system composed of a $6890 \mathrm{~N}$ GC and a 5975C MS, operating in EI mode at $70 \mathrm{eV}$. The $\mathrm{GC}$ was fitted with a non-polar Teknokroma Sapiens-X $5 \mathrm{~ms} 0.25 \mu \mathrm{m}, 30 \mathrm{~m} \times 0.25 \mathrm{~mm}$, column. The temperature ramp was $36^{\circ} \mathrm{C}$ for $1 \mathrm{~min}, 5{ }^{\circ} \mathrm{C} \mathrm{min}{ }^{-1}$ up to $325^{\circ} \mathrm{C}$ and hold time $10 \mathrm{~min}$. The temperature of the inlet, source and transfer line was 250 , 230 and $300{ }^{\circ} \mathrm{C}$, respectively.

\section{Results and discussion}

\subsection{Comparative degradation by $\mathrm{AO}-\mathrm{H}_{2} \mathrm{O}_{2}, \mathrm{EF}$ and $\mathrm{PEF}$ in sulfate medium}

First assays to degrade solutions of $1.03 \mathrm{mM}$ 4-hydroxyphenylacetic acid ( $100 \mathrm{mg} \mathrm{L}^{-1} \mathrm{TOC}$ ) in $0.050 \mathrm{M} \mathrm{Na}_{2} \mathrm{SO}_{4}$ at $\mathrm{pH} 3.0$ aimed at comparing the relative oxidation ability of $\mathrm{AO}-\mathrm{H}_{2} \mathrm{O}_{2}, \mathrm{EF}$ and $\mathrm{PEF}$ at $16.7 \mathrm{~mA} \mathrm{~cm}^{-2}$. The solution $\mathrm{pH}$ did not changed significantly, slightly decreasing to $2.7-2.8$ owe to the generation of acidic by-products $[13,14,38]$.

Fig. 1 depicts a gradual TOC abatement over electrolysis time in all cases, attaining a final reduction of $69 \%, 86 \%$ and $98 \%$ for AO- $\mathrm{H}_{2} \mathrm{O}_{2}$, EF and PEF, respectively. A slightly faster mineralization can be observed in EF compared to PEF up to $120 \mathrm{~min}$. These findings allow concluding that the power of EAOPs rises in the order AO- $\mathrm{H}_{2} \mathrm{O}_{2}<$ EF $<$ PEF for electrolysis times $>120$ min, reaching an almost total mineralization with powerful PEF.

The good oxidation ability of $\mathrm{AO}-\mathrm{H}_{2} \mathrm{O}_{2}$ can be related to the pre-eminent action of physisorbed hydroxyl radical formed from water oxidation at the BDD anode surface $[12,42,43]$ :

$$
\mathrm{BDD}+\mathrm{H}_{2} \mathrm{O} \rightarrow \mathrm{BDD}(\cdot \mathrm{OH})+\mathrm{H}^{+}+\mathrm{e}^{-}
$$

In $\mathrm{AO}-\mathrm{H}_{2} \mathrm{O}_{2}$, organics can be simultaneously degraded by other ROS like $\mathrm{H}_{2} \mathrm{O}_{2}$ and its oxidation product, $\mathrm{HO}_{2}{ }^{*}$ [14]. Moreover, other weak species like peroxodisulfate ion $\left(\mathrm{S}_{2} \mathrm{O}_{8}{ }^{2-}\right)$ and $\mathrm{O}_{3}$ formed at the BDD anode via Reactions (5) and (6), respectively, can be formed $[12,43]$ :

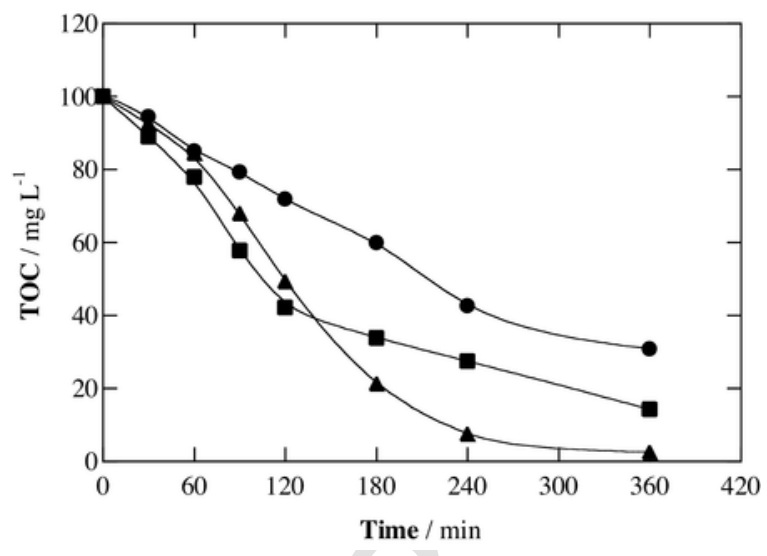

Fig. 1. TOC abatement with electrolysis time for the treatment of $100 \mathrm{~mL}$ of $1.03 \mathrm{mM}$ 4-hydroxyphenylacetic acid solutions in $0.050 \mathrm{M} \mathrm{Na}_{2} \mathrm{SO}_{4}$ at $\mathrm{pH} 3.0$ using a tank reactor equipped with a $3 \mathrm{~cm}^{2} \mathrm{BDD}$ anode and a $3 \mathrm{~cm}^{2}$ air-diffusion cathode at $16.7 \mathrm{~mA} \mathrm{~cm}$ and $35^{\circ} \mathrm{C}$. Method: $(\bigcirc)$ anodic oxidation with electrogenerated $\mathrm{H}_{2} \mathrm{O}_{2}\left(\mathrm{AO}-\mathrm{H}_{2} \mathrm{O}_{2}\right)$, $(\square)$ electro-Fenton (EF) with $0.50 \mathrm{mM} \mathrm{Fe}^{2+}$ and $(\boldsymbol{\Delta})$ photoelectro-Fenton (PEF) with $0.50 \mathrm{mM} \mathrm{Fe}^{2+}$ and $6 \mathrm{~W}$ UVA radiation.

$$
\begin{aligned}
& 2 \mathrm{SO}_{4}{ }^{2-} \rightarrow \mathrm{S}_{2} \mathrm{O}_{8}{ }^{2-}+2 \mathrm{e}^{-} \\
& 3 \mathrm{H}_{2} \mathrm{O} \rightarrow \mathrm{O}_{3}+6 \mathrm{H}^{+}+6 \mathrm{e}^{-}
\end{aligned}
$$

The enhancement of the degradation using EF can be explained by the additional production of ${ }^{\circ} \mathrm{OH}$ in the bulk through homogeneous catalysis with added $\mathrm{Fe}^{2+}$ via Fenton's Reaction (7) $[14,15,27,33]$. Organics are then destroyed by heterogeneous and homogeneous oxidants, i.e., $\mathrm{BDD}\left({ }^{\bullet} \mathrm{OH}\right)$ and ${ }^{\bullet} \mathrm{OH}$.

$$
\mathrm{H}_{2} \mathrm{O}_{2}+\mathrm{Fe}^{2+} \rightarrow \mathrm{Fe}^{3+}+\cdot \mathrm{OH}+\mathrm{OH}^{-}
$$

The faster mineralization in PEF is due to the photolysis of some by-products upon UVA light irradiation, which induces the photoreduction of $\mathrm{Fe}(\mathrm{OH})^{2+}$ to $\mathrm{Fe}^{2+}$ via Reaction (8) and the photolysis of $\mathrm{Fe}(\mathrm{III})$ complexes with final carboxylic acids by Reaction (9) $[36-39,41]$ :

$$
\begin{aligned}
& \mathrm{Fe}(\mathrm{OH})^{2+}+h v \rightarrow \mathrm{Fe}^{2+}+\cdot \mathrm{OH} \\
& \mathrm{Fe}(\mathrm{OOCR})^{2+}+h v \rightarrow \mathrm{Fe}^{2+}+\mathrm{CO}_{2}+\mathrm{R}^{\bullet}
\end{aligned}
$$

The fact that the mineralization rate in EF is slightly higher than that in PEF up to $120 \mathrm{~min}$ of electrolysis (see Fig. 1) suggests the formation of more recalcitrant benzenic by-products at the beginning of the PEF process under the action of UVA light, which are more hardly oxidizable by $\operatorname{BDD}\left({ }^{\bullet} \mathrm{OH}\right)$ and ${ }^{\bullet} \mathrm{OH}$. This behavior is also indicative of little influence of additional ${ }^{\bullet} \mathrm{OH}$ formed from Reaction (8) on TOC decay. In contrast, the faster degradation of PEF at longer times confirms a strong photolytic action of UVA light over the remaining by-products, probably Fe(III) complexes.

The above findings reveal the superiority of PEF for degrading 4-hydroxyphenylacetic acid in sulfate medium. The influence of the main operation parameters on its performance is discussed below, as compared with EF to better clarify the specific role of UVA light. 


\subsection{Effect of operation parameters on EF and PEF processes in sulfate medium}

The concentration of generated hydroxyl radicals in EAOPs and hence, their oxidation ability for wastewater remediation, depends on the applied $j$. The influence of this parameter on the EF and PEF treatments of $1.03 \mathrm{mM}$ 4-hydroxyphenylacetic acid in $0.050 \mathrm{M} \mathrm{Na}_{2} \mathrm{SO}_{4}$ at $\mathrm{pH} 3.0$ was assessed in the range $16.7-100 \mathrm{~mA} \mathrm{~cm}^{-2}$.

For EF, Fig. 2a shows a greater TOC decay at higher $j$. Final TOC reductions of $85.7 \%, 90.1 \%, 93.5 \%$ and $94.8 \%$ were obtained at $16.7,33.3,66.7$ and $100 \mathrm{~mA} \mathrm{~cm}^{-2}$, respectively. This enhancement can be related to the progressive generation of larger amounts of $\mathrm{BDD}\left({ }^{\bullet} \mathrm{OH}\right)$ and ${ }^{\bullet} \mathrm{OH}$ by the concomitant increase in rate of Reactions (4) and (1), thus accelerating Fenton's Reaction (7). The same behavior can be observed in Fig. $2 \mathrm{~b}$ for PEF, although yielding an almost total mineralization $(97.5 \%-98.3 \%)$ for all $j$ values. The effect of this parameter was more evident at shorter times. For example, at $180 \mathrm{~min}$ of electrolysis increasing TOC reductions of $78.8 \%$, $84.6 \%, 89.2 \%$ and $95.5 \%$ were found at growing $j$ values. Comparison of Fig. 2a and b allows concluding not only the superiority of PEF at each $j$, but also the greater relative importance of UVA light as $j$ was raised. After $180 \mathrm{~min}$ at $16.7 \mathrm{~mA} \mathrm{~cm}^{-2}$, for example, $66.2 \mathrm{mg} \mathrm{L}^{-1}$ TOC were abated in EF, rising to $78.8 \mathrm{mg} \mathrm{L}^{-1}$ in PEF. This difference is lower than $15.1 \mathrm{mg} \mathrm{L}^{-1} \mathrm{TOC}$ found at $100 \mathrm{~mA} \mathrm{~cm}^{-2}$. This finding can be explained by the formation of larger quantities of photosensitive by-products at higher $j$, being more rapidly removed upon UVA irradiation.

Fig. 3a and $\mathrm{b}$ depict a drop in MCE values with increasing $j$ for both, EF and PEF, in contrast to its positive contribution to TOC re-

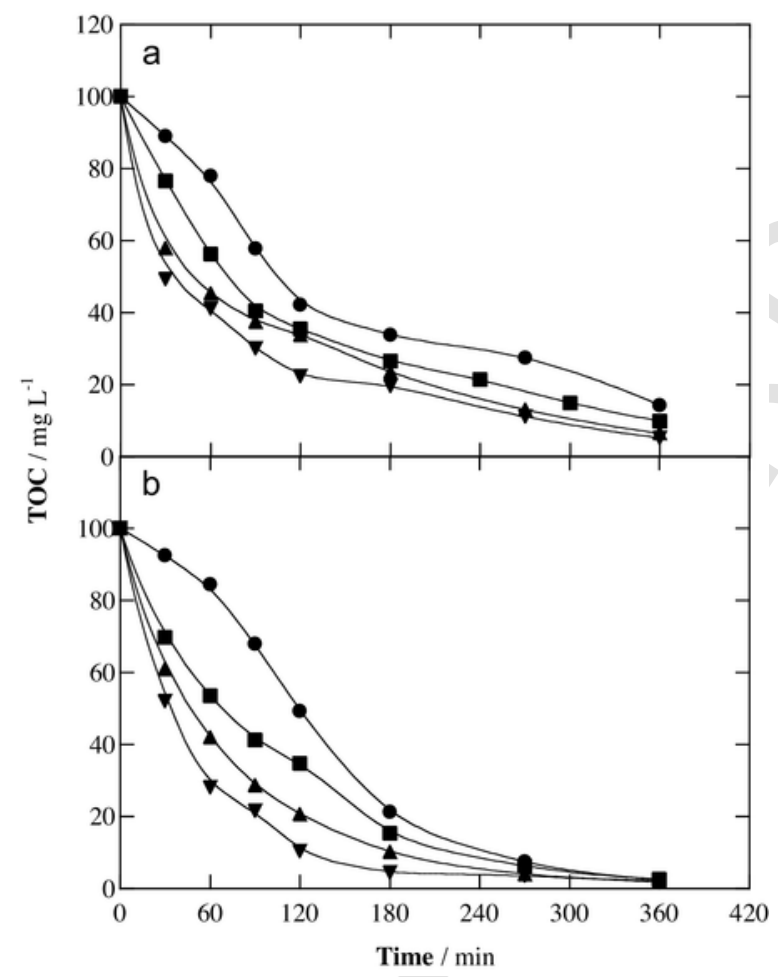

Fig. 2. Effect of current density on TOC decay with electrolysis time for the (a) $\mathrm{EF}$ and (b) PEF treatments of $100 \mathrm{~mL}$ of a $1.03 \mathrm{mM}$ 4-hydroxyphenylacetic acid solution in $0.050 \mathrm{M} \mathrm{Na}_{2} \mathrm{SO}_{4}$ with $0.50 \mathrm{mM} \mathrm{Fe}{ }^{2+}$ at $\mathrm{pH} 3.0$ and $35^{\circ} \mathrm{C}$ using a BDD/ air-diffusion cell. Applied current density: () $16.7 \mathrm{~mA} \mathrm{~cm}^{-2}$, (ם) $33.3 \mathrm{~mA} \mathrm{~cm}^{-2}$, ( $66.7 \mathrm{~mA} \mathrm{~cm}^{-2}$ and (V) $100 \mathrm{~mA} \mathrm{~cm}^{-2}$.

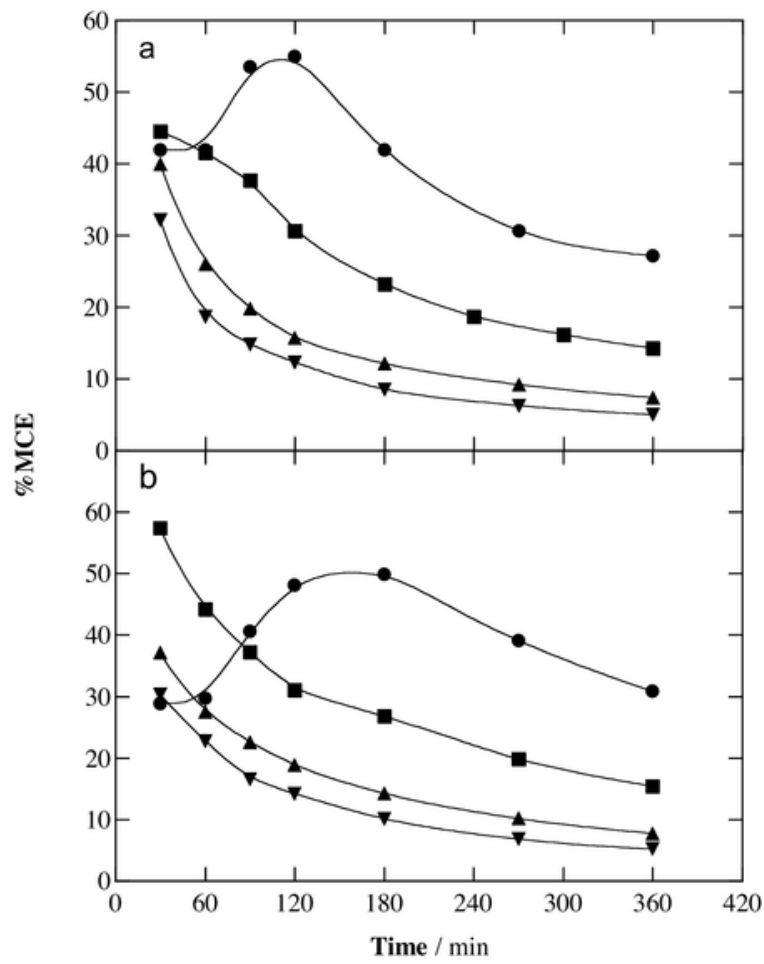

Fig. 3. Mineralization current efficiency vs. electrolysis time for the trials of Fig. 2.

moval. Maximum current efficiencies of $54.9 \%$ for $\mathrm{EF}$ and $49.9 \%$ for PEF were then found at the lowest $j$, dropping to $27.1 \%$ and $30.8 \%$, respectively. In all cases, the MCE values decreased at prolonged time due to the loss of organic load and the formation of more recalcitrant by-products $[12,13]$. It is also noticeable that only the MCE- $t$ plots at the lowest $j$ of $16.7 \mathrm{~mA} \mathrm{~cm}^{-2}$ presented a marked maximal at $120 \mathrm{~min}$ for EF (see Fig. 3a) and at about 180 min for PEF (see Fig. 3b). This can be related to the smaller amounts of $\operatorname{BDD}\left(\bullet^{\circ} \mathrm{OH}\right)$ and ${ }^{\bullet} \mathrm{OH}$ radicals produced at this low $j$, which destroy slowly the primary recalcitrant benzenic by-products. As a result, species that are more prone to being mineralized are gradually generated up to reach the maximum value of current efficiency, whereas the loss of organic load and the formation of $\mathrm{Fe}(\mathrm{III})$-carboxylate products cause a progressive decay in current efficiency at longer time.

The decay in MCE with rising $j$ can be related to the acceleration of parasitic reactions of $\operatorname{BDD}\left({ }^{\bullet} \mathrm{OH}\right)$ and ${ }^{\bullet} \mathrm{OH}$, leading to smaller available quantities. Examples include the following ones [12-14,36-39]:

$$
\begin{aligned}
& 2 \mathrm{BDD}(\cdot \mathrm{OH}) \rightarrow 2 \mathrm{BDD}+\mathrm{O}_{2}+2 \mathrm{H}^{+}+2 \mathrm{e}^{-} \\
& 2 \cdot \mathrm{OH} \rightarrow \mathrm{H}_{2} \mathrm{O}_{2} \\
& \mathrm{H}_{2} \mathrm{O}_{2}+\cdot \mathrm{OH} \rightarrow \mathrm{HO}_{2} \cdot+\mathrm{H}_{2} \mathrm{O} \\
& \mathrm{Fe}^{2+}+\cdot \mathrm{OH} \rightarrow \mathrm{Fe}^{3+}+\mathrm{OH}^{-}
\end{aligned}
$$

The substrate concentration is another important variable since it affects the attack of oxidants on organic molecules in competence with parasitic reactions. To study the effect of this parameter on the performance of the EF and PEF treatments, solutions with 
$0.21-2.06 \mathrm{mM}$ of the pollutant in $0.050 \mathrm{M} \mathrm{Na}_{2} \mathrm{SO}_{4}$ at $\mathrm{pH} 3.0$ were treated at $33.3 \mathrm{~mA} \mathrm{~cm}^{-2}$ for $360 \mathrm{~min}$. Fig. $4 \mathrm{a}$ and $\mathrm{b}$ confirm the superiority of PEF over EF to remove 4-hydroxyphenylacetic acid and its by-products for all substrate contents. At $360 \mathrm{~min}$, TOC was reduced by $72.1 \%, 82.3 \%, 90.1 \%$ and $79.3 \%$ in EF and $92.2 \%, 95.4 \%$, $97.5 \%$ and $88.8 \%$ in PEF for $0.21,0.51,1.03$ and $2.06 \mathrm{mM}$, respectively. The best performance was achieved for the $1.03 \mathrm{mM}$ solution, further declining. Worth noting, a larger TOC amount was removed at greater substrate concentration. After $360 \mathrm{~min}$ of EF and PEF, for example, 158.6 and $177.5 \mathrm{mg} \mathrm{L}^{-1}$ TOC were destroyed when starting with $2.06 \mathrm{mM}$, values much greater than $100 \mathrm{mg} \mathrm{L}^{-1}$ TOC corresponding to the $1.03 \mathrm{mM}$ solution.

The enhancement of the oxidation ability at higher substrate concentrations is easily corroborated from the corresponding MCE values given in Fig. 5a and b. In both treatments, the highest efficiency was obtained for $2.06 \mathrm{mM}$. Since the same amount of hydroxyl radicals is expected to be produced in all treatments at equal $j$, a larger number of organic molecules react with $\operatorname{BDD}\left({ }^{\bullet} \mathrm{OH}\right)$ and $\bullet$ OH, thus decelerating parasitic Reactions (10)-(13). Note again the continuous drop of MCE values over time, as also stated above.

In conclusion, the powerful PEF leads to an almost total mineralization of 4-hydroxyphenylacetic acid solutions, with 98\% TOC removal as maximal. This is due to the large photolytic action of UVA radiation to destroy photoactive by-products that are slowly removed by hydroxyl radicals in EF.

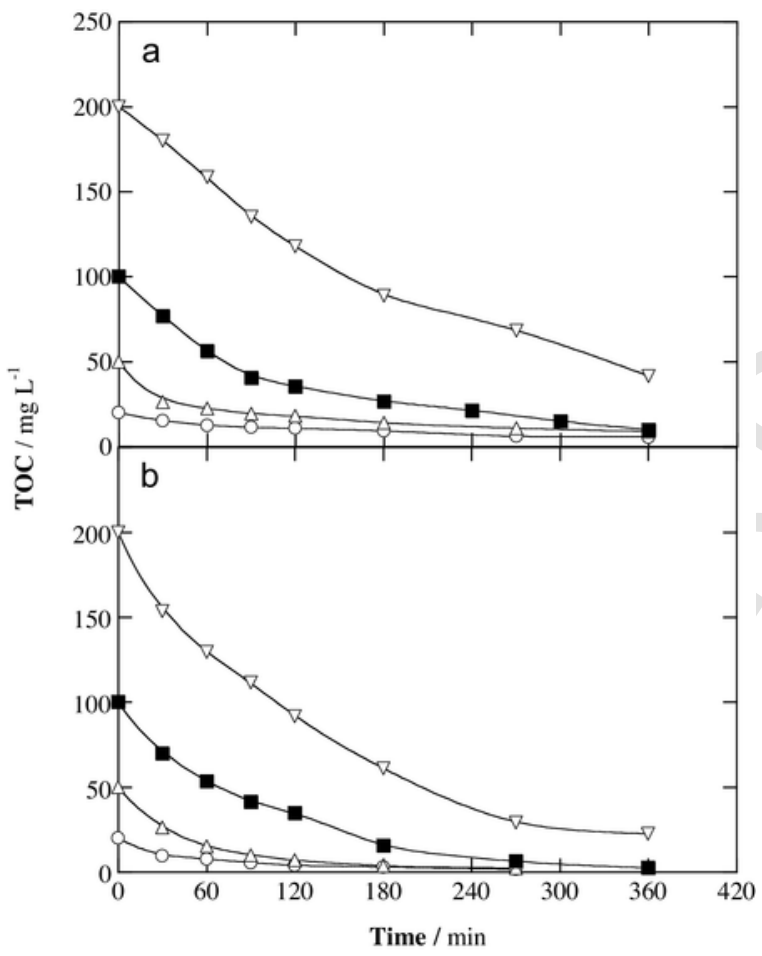

Fig. 4. Influence of pollutant concentration on TOC removal with electrolysis time for the degradation of $100 \mathrm{~mL}$ of 4-hydroxyphenylacetic acid solutions in $0.050 \mathrm{M} \mathrm{Na}_{2} \mathrm{SO}_{4}$ with $0.50 \mathrm{mM} \mathrm{Fe}^{2+}$ at $\mathrm{pH} 3.0$ using a BDD/air-diffusion cell at $33.3 \mathrm{~mA} \mathrm{~cm}{ }^{-2}$ and $35^{\circ} \mathrm{C}$. Method: (a) EF and (b) PEF. 4-Hydroxyphenylacetic acid concentration: (O) $0.21 \mathrm{mM}$, $(\triangle) 0.51 \mathrm{mM},(\square) 1.03 \mathrm{mM}$ and $(\nabla) 2.06 \mathrm{mM}$.

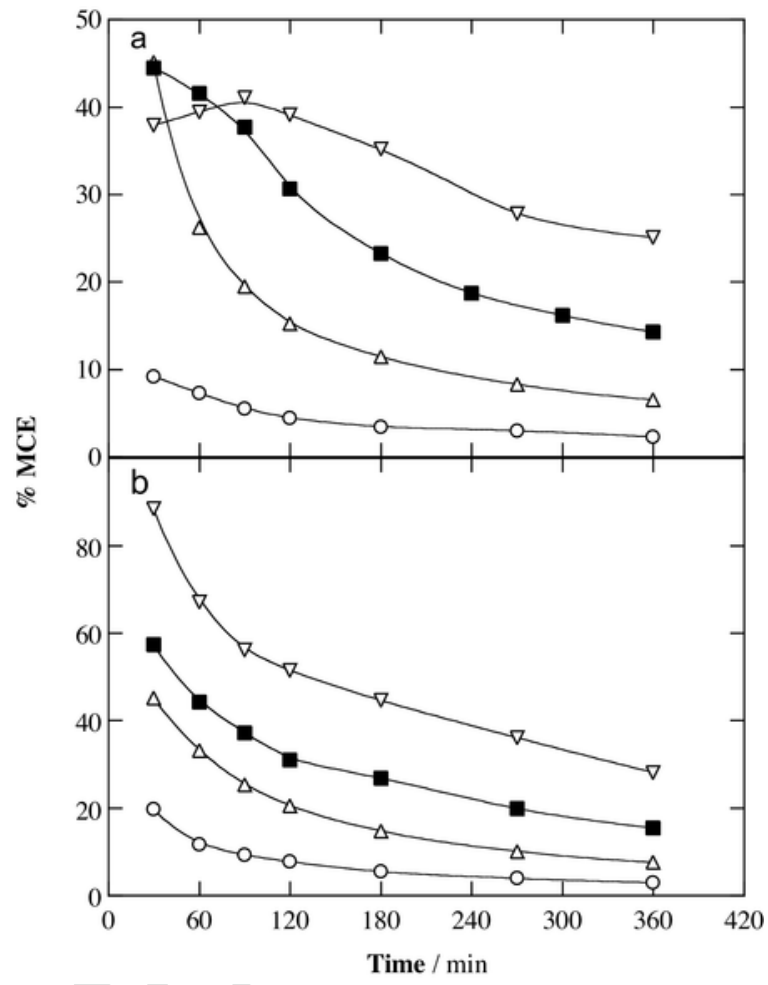

Fig. 5. Time course of mineralization current efficiency for the assays of Fig. 4.

\subsection{Decay kinetics of 4-hydroxyphenylacetic acid in sulfate medium by $E F$ and $P E F$}

The reaction of 4-hydroxyphenylacetic acid with generated oxidants was monitored by reversed-phase HPLC. Fig. 6 illustrates the exponential concentration decay for a $1.03 \mathrm{mM}$ substrate solution in $0.050 \mathrm{M} \mathrm{Na}_{2} \mathrm{SO}_{4}$ at $\mathrm{pH} 3.0$ treated by EF and PEF at $33.3 \mathrm{~mA} \mathrm{~cm}^{-2}$, disappearing in 60 and $40 \mathrm{~min}$, respectively. One can infer that the main oxidant in EF and $\mathrm{PEF}$ is ${ }^{\circ} \mathrm{OH}$ in the bulk. The slightly faster

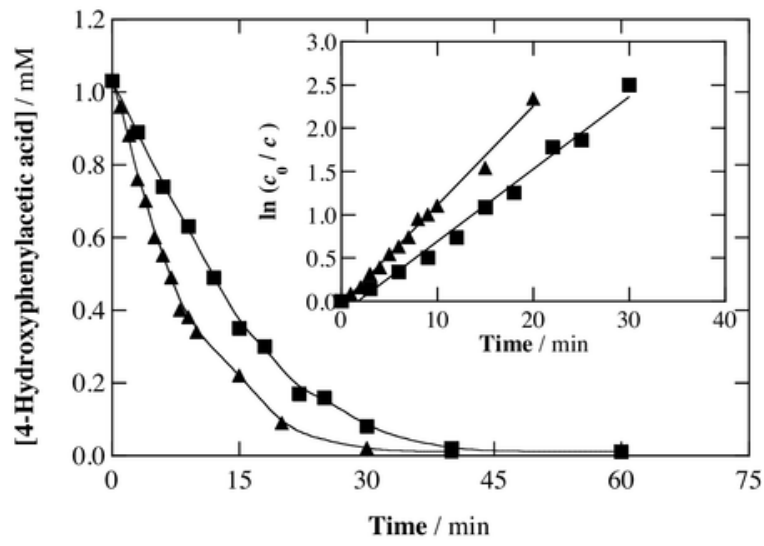

Fig. 6. Decay of 4-hydroxyphenylacetic acid concentration with electrolysis time for the (ם) EF and (A) PEF degradations of $100 \mathrm{~mL}$ of pollutant solutions in $0.050 \mathrm{M} \mathrm{Na}_{2} \mathrm{SO}_{4}$ with $0.50 \mathrm{mM} \mathrm{Fe}^{2+}$ at pH 3.0 using a BDD/air-diffusion cell at $33.3 \mathrm{~mA} \mathrm{~cm}{ }^{-2}$ and $35^{\circ} \mathrm{C}$. The inset panel presents the kinetic analysis assuming a pseudo-first-order reaction for 4-hydroxyphenylacetic acid. 
destruction in PEF can then be ascribed to the generation of additional amounts of $\bullet \mathrm{OH}$ by photolytic Reaction (8).

The inset panel of Fig. 6 presents the good fitting for the drop of substrate concentrations according to a pseudo-first-order kinetic equation. From these straight lines, apparent rate constants $\left(k_{1}\right)$ of $1.4 \times 10^{-3} \mathrm{~s}^{-1}\left(R^{2}=0.990\right)$ for EF and $1.9 \times 10^{-3} \mathrm{~s}^{-1}\left(R^{2}=0.992\right)$ for PEF were obtained. This behavior suggests the attack of a steady and low $\bullet \mathrm{OH}$ concentration on 4-hydroxyphenylacetic acid obeying the following second-order reaction rate $(r)$ :

$$
r=k_{2}[\bullet \mathrm{OH}][\mathrm{R}]=k_{1}[\mathrm{R}]
$$

where $k_{2}\left(=k_{1} /\left[\bullet^{\bullet} \mathrm{OH}\right]\right)$ is the absolute or second-order rate constant and $\mathrm{R}$ denotes the 4-hydroxyphenylacetic acid. Taking into account that $k_{2}=7.02 \times 10^{8} \mathrm{M}^{-1} \mathrm{~s}^{-1}$ for this reaction [11], one can estimate the action of average ${ }^{\circ} \mathrm{OH}$ concentrations $\left(=k_{1} / k_{2}\right)$ of $2.0 \times 10^{-11}$ and $2.7 \times 10^{-11} \mathrm{M}$ for $\mathrm{EF}$ and $\mathrm{PEF}$, respectively.

\subsection{Time-course of final carboxylic acids during EF and PEF in sulfate medium}

Ion-exclusion chromatograms revealed the accumulation of large concentrations of oxalic acid during the EF and PEF treatments. It is a typical short-chain carboxylic acid by-product that forms Fe(III) complexes that can be directly converted into $\mathrm{CO}_{2}$ [21,27,33,34]. Fig. 7 depicts the evolution of oxalic acid concentration during the treatment of a $1.03 \mathrm{mM}$ 4-hydroxyphenylacetic acid solution at $33.3 \mathrm{~mA} \mathrm{~cm}$. In EF it was progressively accumulated up to $0.32 \mathrm{mM}$ at $150 \mathrm{~min}$, whereupon it dropped drastically to $0.072 \mathrm{mM}$ at the end of the electrolysis. This corresponds to $1.70 \mathrm{mg} \mathrm{L}^{-1} \mathrm{TOC}$, which accounts for $17.1 \%$ of the remaining TOC (see Fig. 2a). The final solution of EF then contained a large proportion of by-products that are even more hardly oxidized by $\mathrm{BDD}\left({ }^{\circ} \mathrm{OH}\right)$ and/or ${ }^{\bullet} \mathrm{OH}$ than final carboxylic acids. In contrast, Fig. 7 shows that in PEF oxalic acid was much more rapidly accumulated, up to $0.32 \mathrm{mM}$ in $60 \mathrm{~min}$, and completely removed in 240 min because of the rapid photolysis of Fe(III)-oxalate complexes by UVA light via Reaction (9). At that time, the solution contained $18.7 \mathrm{mg} \mathrm{L}^{-1}$ TOC (see Fig. 2b), which was reduced to $2.5 \mathrm{mg} \mathrm{L}^{-1}$ at $360 \mathrm{~min}$. This means that the combined action of BDD( $\bullet \mathrm{OH}),{ }^{\bullet} \mathrm{OH}$ and UVA light over remaining photoactive by-products strongly enhances the mineralization process.

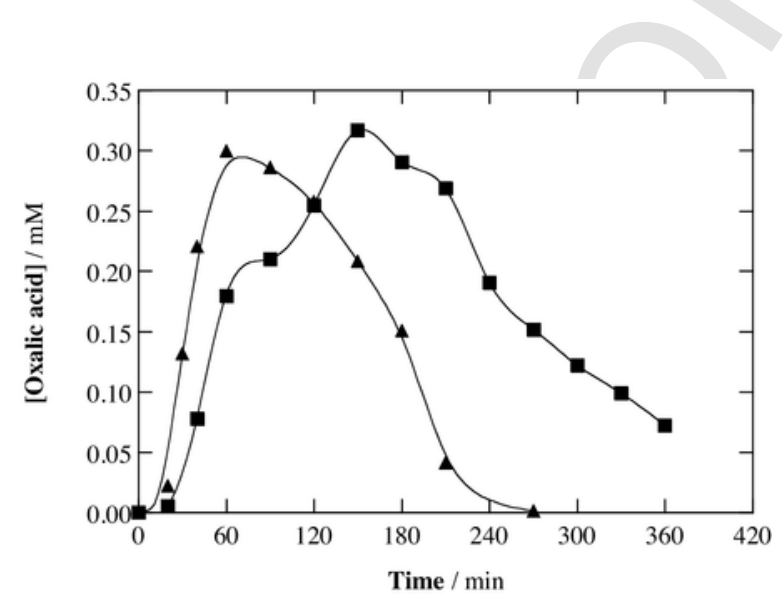

Fig. 7. Evolution of the concentration of oxalic acid detected during the treatments

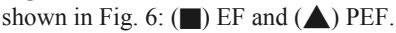

\subsection{Degradation of 4-hydroxyphenylacetic acid in a real OOMW matrix}

The study of the degradation of 4-hydroxyphenylacetic acid was extended to a real OOMW, the matrix that conveys the pollutant to the aquatic environment. Table 1 summarizes the physicochemical properties of the OOMW sample. The raw sample had: (i) neutral $\mathrm{pH}$, (ii) very low conductivity and (iii) high turbidity, TOC, COD, TSS and TS. After filtration with an $18 \mu \mathrm{m}$ filter, the conditioned OOMW showed a drastic removal of turbidity, TSS and TS. Its phenol index was low, with larger contents of oil and grease. The $\mathrm{BOD}_{5} / \mathrm{COD}=0.334$ for the conditioned OOMW spiked with $1.03 \mathrm{mM}$ 4-hydroxyphenylacetic acid informed about its low biodegradability. The conditioned OOMW also contained: (i) a very high concentration of $\mathrm{SO}_{4}{ }^{2-}$ compared to the very small contents of $\mathrm{NO}_{3}{ }^{-}$and $\mathrm{Cl}^{-}$as anions and (ii) the predominance of $\mathrm{K}^{+}$and $\mathrm{Na}^{+}$ among the cations, with an insignificant content of $\mathrm{Fe}^{2+}$. On the other hand, its GC-MS analysis revealed the presence of a large variety of compounds like 7 phenolic molecules, including 4-hydroxyphenylacetic acid, 1 heteroaliphatic alcohol as well as 4 aromatic and 4 aliphatic (1 cyclic and 3 linear) carboxylic acids, as summarized in Table 2.

The EAOPs were then applied to the degradation of the conditioned OOMW after spiking or not $1.03 \mathrm{mM}$ 4-hydroxyphenylacetic acid, as well as spiked OOMW samples diluted to $60 \%$ and $20 \%$ (v/ v) with ultrapure water. The initial $\mathrm{pH}$ was adjusted to 3.0 with $\mathrm{H}_{2} \mathrm{SO}_{4}$ and trials were carried out at $16.7 \mathrm{~mA} \mathrm{~cm}^{-2}$ for $540 \mathrm{~min}$. This small $j$ was chosen because of the large potential difference of the cell arising from the low conductivity of the raw OOMW (see Table 1). Trials were performed with the conditioned sample to avoid the influence of suspended solids, particularly on the absorption of the irradiated UVA light.

Table 1

Main physicochemical characteristics of the raw and conditioned OOMW sample to be further used for electrochemical treatment.

\begin{tabular}{|c|c|}
\hline Parameter (units) & OOMW \\
\hline $\mathrm{pH}$ & $6.8 \pm 0.1^{\mathrm{a}}$ \\
\hline Conductivity $\left(\mathrm{mS} \mathrm{cm}^{-1}\right)$ & $1.5 \pm 0.1^{\mathrm{a}}$ \\
\hline Turbidity (NTU) & $\begin{aligned} 245.7 & \pm 14.0^{\mathrm{a}} \\
24.0 & \pm 0.1^{\mathrm{b}}\end{aligned}$ \\
\hline TOC $\left(\mathrm{mg} \mathrm{L}^{-1}\right)$ & $\begin{array}{c}598 \pm 42^{\mathrm{a}} \\
505 \pm 31^{\mathrm{b}}\end{array}$ \\
\hline $\operatorname{COD}\left(\mathrm{mg} \mathrm{O}_{2} \mathrm{~L}^{-1}\right)$ & $2368 \pm 1^{c}$ \\
\hline $\mathrm{BOD}_{5}\left(\mathrm{mg} \mathrm{O}_{2} \mathrm{~L}^{-1}\right)$ & $790 \pm 42^{c}$ \\
\hline $\mathrm{BOD}_{5} / \mathrm{COD}$ & $0.334 \pm 0.012^{\mathrm{c}}$ \\
\hline $\operatorname{TSS}\left(\mathrm{mg} \mathrm{L}^{-1}\right)$ & $\begin{array}{c}3712 \pm 398^{\mathrm{a}} \\
82 \pm 41^{\mathrm{b}}\end{array}$ \\
\hline $\mathrm{TS}\left(\mathrm{mg} \mathrm{L}^{-1}\right)$ & $\begin{array}{r}5852 \pm 284^{\mathrm{a}} \\
2107 \pm 51^{\mathrm{b}}\end{array}$ \\
\hline Phenol index $\left(\mathrm{mg} \mathrm{L}^{-1}\right)$ & $9.3 \pm 0.21^{\mathrm{b}}$ \\
\hline Oil and grease $\left(\mathrm{mg} \mathrm{L}^{-1}\right)$ & $60^{\mathrm{b}}$ \\
\hline $\mathrm{NO}_{2}^{-}\left(\mathrm{mg} \mathrm{L}^{-1}\right)$ & $<0.012^{\mathrm{b}, \mathrm{d}}$ \\
\hline $\mathrm{NO}_{3}^{-}\left(\mathrm{mg} \mathrm{L}^{-1}\right)$ & $0.51^{\mathrm{b}}$ \\
\hline $\mathrm{SO}_{4}^{2-}\left(\mathrm{mg} \mathrm{L}^{-1}\right)$ & $910.31^{b}$ \\
\hline $\mathrm{Cl}^{-}\left(\mathrm{mg} \mathrm{L}^{-1}\right)$ & $2.91^{\mathrm{b}}$ \\
\hline $\mathrm{Fe}^{2+}\left(\mathrm{mg} \mathrm{L}^{-1}\right)$ & $1.35^{\mathrm{b}}$ \\
\hline $\mathrm{Ca}^{2+}\left(\mathrm{mg} \mathrm{L}^{-1}\right)$ & $15.11^{\mathrm{b}}$ \\
\hline $\mathrm{Mg}^{2+}\left(\mathrm{mg} \mathrm{L}^{-1}\right)$ & $16.41^{\mathrm{b}}$ \\
\hline $\mathrm{K}^{+}\left(\mathrm{mg} \mathrm{L}^{-1}\right)$ & $76.81^{\mathrm{b}}$ \\
\hline $\mathrm{Na}^{+}\left(\mathrm{mg} \mathrm{L}^{-1}\right)$ & $387.81^{\mathrm{b}}$ \\
\hline
\end{tabular}

a Raw OOMW sample.

b After filtration with an $18 \mu \mathrm{m}$ filter.

c After filtration (as in b) and addition of $1.03 \mathrm{mM}$ 4-hydroxyphenylacetic acid.

${ }^{\text {d }}$ Limit of quantification. 
Table 2

Organic compounds identified by GC-MS using a non-polar column for a lyophilized real OOMW sample after filtration with an $18 \mu \mathrm{m}$ filter.

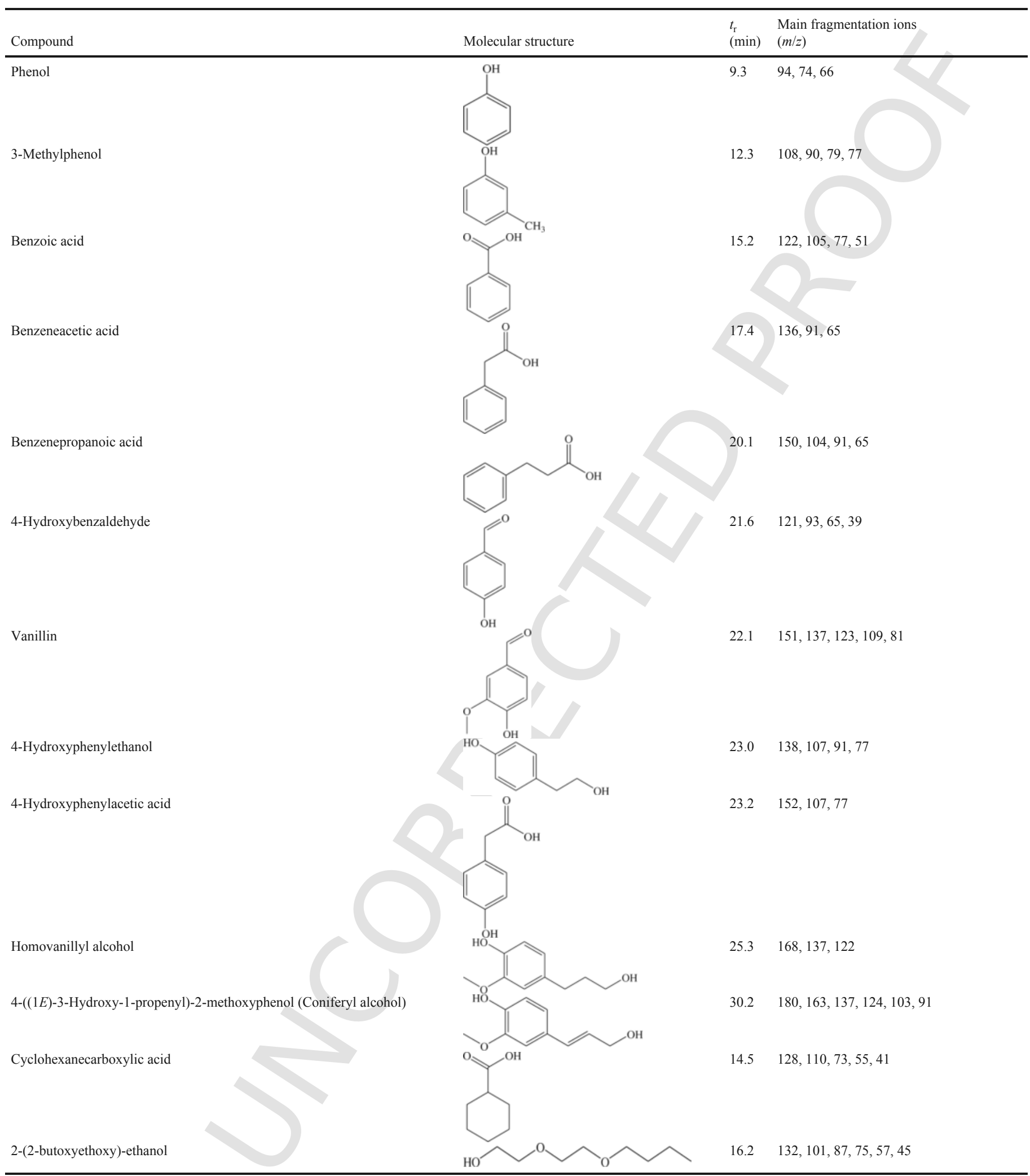


Table 2 (Continued)

\begin{tabular}{|c|c|c|c|}
\hline Compound & Molecular structure & $\begin{array}{l}t_{\mathrm{r}} \\
(\min )\end{array}$ & $\begin{array}{l}\text { Main fragmentation ions } \\
(\mathrm{m} / \mathrm{z})\end{array}$ \\
\hline$n$-Heptanoic acid & & 5.0 & $130,87,73,60$ \\
\hline$n$-Hexadecanoic acid (Palmitic acid) & & 34.1 & $256,213,171,157,129,97,73,60,43$ \\
\hline Oleic acid & & 37.2 & $282,264,129,111,97,83,69,55,41$ \\
\hline
\end{tabular}

Fig. 8a-c depict the same relative oxidation ability of the EAOPs in the sequence $\mathrm{AO}-\mathrm{H}_{2} \mathrm{O}_{2}<\mathrm{EF}<\mathrm{PEF}$ for all the media tested. Partial mineralization of the conditioned undiluted OOMW (not spiked) was obtained with final TOC reductions of $71.8 \%, 79.5 \%$ and $83.4 \%$ for the above treatments. This indicates an effective attack of $\operatorname{BDD}\left({ }^{\bullet} \mathrm{OH}\right)$

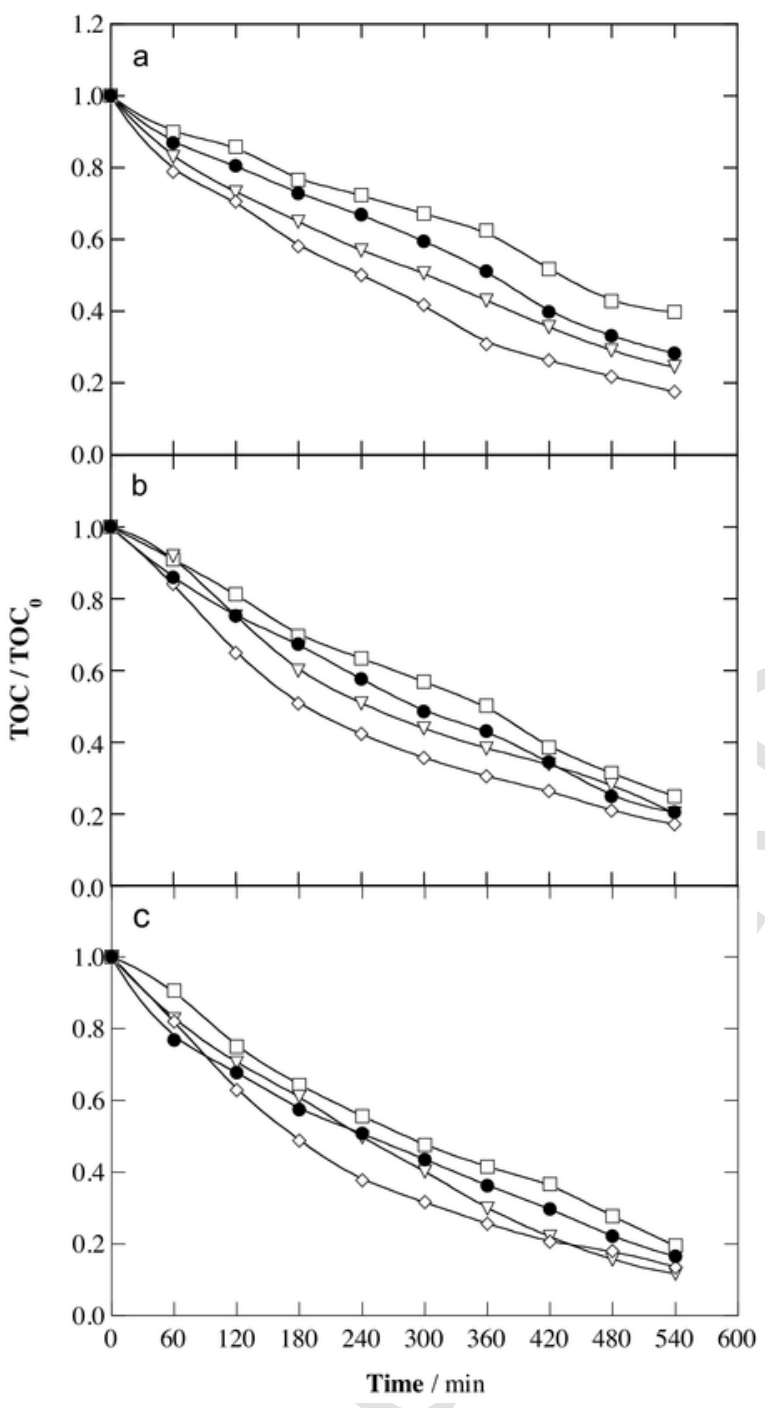

Fig. 8. Normalized TOC removal vs. electrolysis time for: (a) $\mathrm{AO}-\mathrm{H}_{2} \mathrm{O}_{2}$, (b) EF with $0.50 \mathrm{mM} \mathrm{Fe}^{2+}$ and (c) PEF with $0.50 \mathrm{mM} \mathrm{Fe}^{2+}$ and $6 \mathrm{~W}$ UVA radiation treatments of $100 \mathrm{~mL}$ of solutions with $(\square) 100 \%,(\nabla) 60 \%$ and $(\diamond) 20 \%(\mathrm{v} / \mathrm{v})$ of filtered $(18 \mu \mathrm{m})$ real OOMW, in the $(\bullet)$ absence or $(\square, \nabla, \diamond)$ presence of $1.03 \mathrm{mM}$ 4-hydroxyphenylacetic acid at pH 3.0 using a stirred $\mathrm{BDD} /$ air-diffusion tank reactor at $16.7 \mathrm{~mA} \mathrm{~cm}^{-2}$ and $35^{\circ} \mathrm{C}$. on the organics contained in the real OOMW in $\mathrm{AO}-\mathrm{H}_{2} \mathrm{O}_{2}$, which was enhanced under the parallel action of ${ }^{\bullet} \mathrm{OH}$ in $\mathrm{EF}$ and became even more efficient upon photolysis of photoactive by-products in PEF. This behavior was also found after spiking $1.03 \mathrm{mM}$ 4-hydroxyphenylacetic acid to the undiluted OOMW $(100 \%(\mathrm{v} / \mathrm{v}))$ and to diluted OOMW samples. Fig. 8a-c highlights a slight enhancement of the normalized TOC abatement when decreasing the organic concentration of the treated effluent. The quickest mineralization was achieved for the $20 \%$ (v/v) solution reaching $82.5 \%, 83.0 \%$ and $86.4 \%$ TOC decay by AO- $\mathrm{H}_{2} \mathrm{O}_{2}$, EF and PEF, respectively. However, since the initial TOC decreased significantly from $605 \mathrm{mg} \mathrm{L}^{-1}$ corresponding to the $100 \%$ $(\mathrm{v} / \mathrm{v})$ solution, one can infer that all the treatments were more efficient at greater organic load, confirming the deceleration of their parasitic Reactions (10)-(13).

The decay kinetics of the spiked 4-hydroxyphenylacetic acid in the above assays was followed by reversed-phase HPLC and compared with that obtained in $0.050 \mathrm{M} \mathrm{Na}_{2} \mathrm{SO}_{4}$. Fig. 9a and $\mathrm{b}$ illustrates the exponential abatement of the concentration of this compound under all experimental conditions, always obeying a pseudo-first-order kinetics, as depicted in their inset panels. Under $\mathrm{AO}-\mathrm{H}_{2} \mathrm{O}_{2}$ conditions (see Fig. 9a), the slow destruction by $\operatorname{BDD}\left({ }^{\bullet} \mathrm{OH}\right)$ led to the complete removal of 4-hydroxyphenylacetic acid in $540 \mathrm{~min}$ for all the OOMW solutions, although its removal was faster at a gradually smaller organic load. Accordingly, the substrate disappeared completely in about $360 \mathrm{~min}$ in $0.050 \mathrm{M} \mathrm{Na}_{2} \mathrm{SO}_{4}$. The $k_{1}$ values varied between $7.3 \times 10^{-5} \mathrm{~s}^{-1}\left(R^{2}=0.985\right)$ for the $100 \%(\mathrm{v} / \mathrm{v})$ solution and $2.0 \times 10^{-4} \mathrm{~s}^{-1}\left(R^{2}=0.992\right)$ for $0.050 \mathrm{M} \mathrm{Na}_{2} \mathrm{SO}_{4}$. Assuming that Reaction (14) is verified for $\operatorname{BDD}\left({ }^{\bullet} \mathrm{OH}\right)$, its average content can be estimated as $k_{1} / k_{2}$, with $k_{2}=7.02 \times 10^{8} \mathrm{M}^{-1} \mathrm{~s}^{-1}$, growing from $1.0 \times 10^{-13}$ to $2.8 \times 10^{-13} \mathrm{M}$. As expected, the substrate decay was much faster by PEF due to the more active ${ }^{\bullet} \mathrm{OH}$ formed from Reactions (7) and (8). Fig. 9b reveals that time for total disappearance varied from 100 to $70 \mathrm{~min}$ when going from $100 \%$ to $20 \%$ (v/v) solutions, decreasing to $50 \mathrm{~min}$ for $0.050 \mathrm{M} \mathrm{Na}_{2} \mathrm{SO}_{4}$. The corresponding $k_{1} \mathrm{val}$ ues increased from $6.8 \times 10^{-4} \mathrm{~s}^{-1}\left(R^{2}=0.993\right)$ for the $100 \%(\mathrm{v} / \mathrm{v})$ solution to $1.4 \times 10^{-3} \mathrm{~s}^{-1}\left(R^{2}=0.993\right)$ for $0.050 \mathrm{M} \mathrm{Na}_{2} \mathrm{SO}_{4}$, with an average $\cdot \mathrm{OH}$ content between $9.7 \times 10^{-13}$ and $2.0 \times 10^{-12} \mathrm{M}$. This corroborates the enhanced oxidation of aromatic products by ${ }^{\bullet} \mathrm{OH}$ than $\mathrm{BDD}(\cdot \mathrm{OH})$ in $\mathrm{PEF}$.

The change in biodegradability of the treated solutions was also evaluated. The initial $\mathrm{BOD}_{5} / \mathrm{COD}$ ratio was 0.334 for the conditioned OOMW spiked with $1.03 \mathrm{mM}$ 4-hydroxyphenylacetic acid, which is close to the biodegradability threshold of 0.4 needed for biological treatment [44]. Fig. 10 shows a decay of the initial $\mathrm{BOD}_{5} / \mathrm{COD}$ ratio after 180 and 360 min of the $\mathrm{AO}-\mathrm{H}_{2} \mathrm{O}_{2}$ treatment, indicating the generation of biorefractory species during electrolysis as well as the effect of accumulated $\mathrm{H}_{2} \mathrm{O}_{2}$. In contrast, the PEF degradation caused a strong enhancement of the biodegradability, with a final $\mathrm{BOD}_{5} / \mathrm{COD}$ value near 0.6 after 360 min of treatment. This means that PEF is not only the most powerful EAOP to decontaminate OOMW, spiked or 

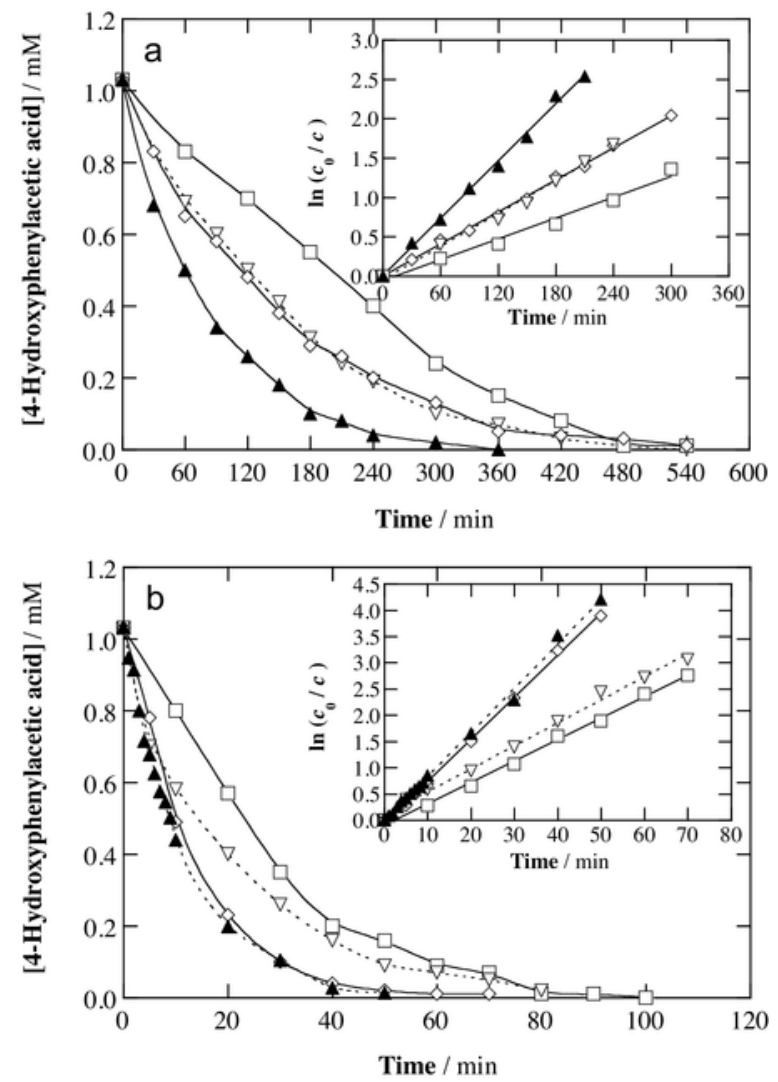

Fig. 9. 4-Hydroxyphenylacetic acid abatement with electrolysis time for the (a) AO- $\mathrm{H}_{2} \mathrm{O}_{2}$ and (b) PEF treatments of $100 \mathrm{~mL}$ of $1.03 \mathrm{mM}$ 4-hydroxyphenylacetic acid solutions in $(\square) 100 \%,(\nabla) 60 \%$ and $(\diamond) 20 \%(\mathrm{v} / \mathrm{v})$ of filtered $(18 \mu \mathrm{m})$ real OOMW, as well as in $(\mathbf{\Delta}) 0.050 \mathrm{M} \mathrm{Na}_{2} \mathrm{SO}_{4}$, all at pH 3.0 using a stirred BDD/air-diffusion tank reactor at $16.7 \mathrm{~mA} \mathrm{~cm}^{-2}$ and $35^{\circ} \mathrm{C}$. The corresponding kinetic analysis considering a pseudo-first-order decay for the pollutant is shown in the inset panels.

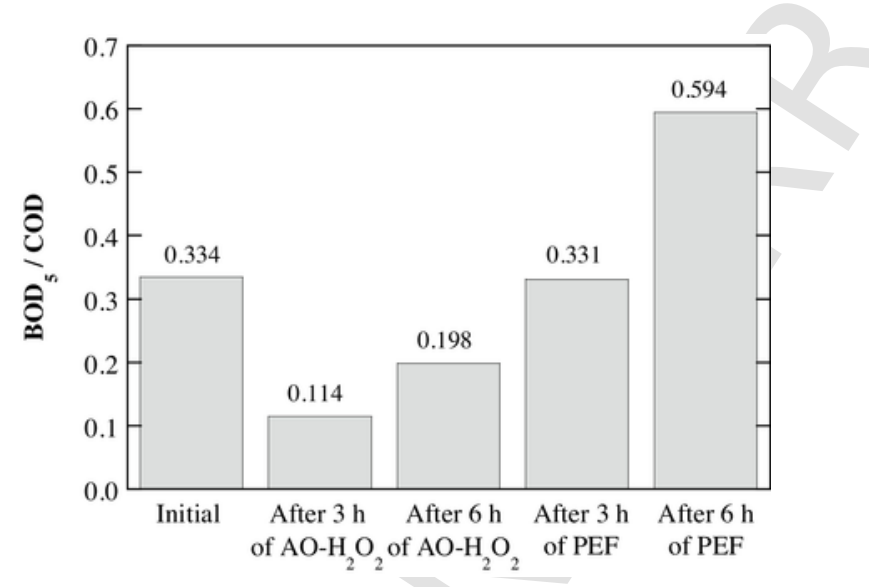

Fig. 10. Change of $\mathrm{BOD}_{5} / \mathrm{COD}$ ratio of the raw OOMW sample (filtered with an $18 \mu \mathrm{m}$ filter) once spiked with $1.03 \mathrm{mM}$ 4-hydroxyphenylacetic acid and treated for 3 and $6 \mathrm{~h}$ by either $\mathrm{AO}-\mathrm{H}_{2} \mathrm{O}_{2}$ or PEF with $0.50 \mathrm{mM} \mathrm{Fe}{ }^{2+}$ and $6 \mathrm{~W}$ UVA radiation.

not with 4-hydroxyphenylacetic acid, but it can also be an optimum process for coupling with biological processes. This suggests a much faster and efficient degradation of this kind of wastewater by means of the coupled $\mathrm{PEF} /$ biological process, if compared to a single step biological treatment, as recently shown for the EF/biological degra- dation of antibiotics furosemide and ranitidine in aqueous medium [44].

\section{Conclusions}

PEF process is the most powerful EAOP for treating 4-hydroxyphenylacetic acid and, what is more relevant for future application, its high performance is maintained in a real wastewater matrix like OOMW. The quick mineralization in PEF was achieved thanks to the photolytic action of UVA radiation on photoactive by-products, as observed for the quick removal of Fe(III)-oxalate complexes formed. The increase in $j$ accelerated the mineralization in all media tested, but with loss of MCE owing to the parasitic reactions that consume the hydroxyl radicals. An enhancement of the oxidation ability of all EAOPs with increasing organic load was always found, with the consequent rise in MCE. This favors the degradation rate of real OOMW with high organic content. 4-Hydroxyphenylacetic acid decay always obeyed a pseudo-first-order kinetics. About $98 \%$ and $80 \%$ TOC reductions were achieved for the PEF treatment of $1.03 \mathrm{mM}$ 4-hydroxyphenylacetic acid in $0.050 \mathrm{M} \mathrm{Na}_{2} \mathrm{SO}_{4}$ and in the real OOMW, respectively. In the latter case, the PEF process also led to a greater biodegradability.

\section{Acknowledgements}

The authors acknowledge financial support from project CTQ2013-48897-C2-1-R (MINECO, FEDER, EU). The PhD fellowship awarded to N. Flores by SENESCYT (Ecuador) is acknowledged as well.

\section{References}

[1] S. Magdich, C. Ben Ahmed, R. Jarboui, B. Ben Rouina, M. Boukhris, E. Ammar, Dose and frequency dependent effects of olive mill wastewater treatment on the chemical and microbial properties of soil, Chemosphere 93 (2013) 1896-1903.

[2] S. Dermeche, M. Nadour, C. Larroche, F. Moulti-Mati, P. Michaud, Olive mill wastes: biochemical characterizations and valorization strategies, Process Biochem. 48 (2013) 1532-1552.

[3] M. DellaGreca, L. Previtera, F. Temussi, A. Zarrelli, Low-molecular-weight components of olive oil mill waste-waters, Phytochem. Anal. 15 (2004) $184-188$.

[4] J.M. Ochando-Pulido, M.D. Victor-Ortega, G. Hodaifa, A. Martinez-Ferez, Physicochemical analysis and adequation of olive oil mill wastewater after advanced oxidation process for reclamation by pressure-driven membrane technology, Sci. Total Environ. 503-504 (2014) 113-121.

[5] D. Pham Minh, P. Gallezot, S. Azabou, S. Sayadi, M. Besson, Catalytic wet air oxidation of olive oil mill effluents, Appl. Catal. B: Environ. 84 (2008) $749-757$.

[6] C. Belaid, M. Kallel, M. Khadhraou, G. Lalleve, B. Elleuch, J.F. Fauvarque, Electrochemical treatment of olive mill wastewaters: removal of phenolic compounds and decolourization, J. Appl. Electrochem. 36 (2006) 1175-1182.

[7] C. Belaid, M. Khadraoui, S. Mseddi, M. Kallel, B. Elleuch, J.F. Fauvarque, Electrochemical treatment of olive mill wastewater: treatment extent and effluent phenolic compounds monitoring using some uncommon analytical tools, J. Environ. Sci. 25 (2013) 220-230.

[8] P.P. Liebgott, M. Labat, A. Amouric, J.L. Tholozan, J. Lorquin, Tyrosol degradation via the homogentisic acid pathway in a newly isolated Halomonas strain from olive processing effluents, J. Appl. Microbiol. 105 (2008) 2084-2095.

[9] S. Ammar, M.A. Oturan, L. Labiadh, A. Guersalli, R. Abdelhedi, N. Oturan, E. Brillas, Degradation of tyrosol by a novel electro-Fenton process using pyrite as heterogeneous source of iron catalyst, Water Res. 74 (2015) 77-87.

[10] I. Sanchez, F. Stueber, A. Fabregat, J. Font, A. Fortuny, C. Bengoa, Degradation of model olive mill contaminants of OMW catalysed by zero-valent iron enhanced with a chelant, J. Hazard. Mater. 199-200 (2012) 328-335.

[11] F.J. Benitez, J.L. Acero, F.J. Real, F.J. Rubio, A. Leal, The role of hydroxyl radicals for the decomposition of p-hydroxy phenylacetic acid in aqueous solutions, Water Res. 35 (2001) 1338-1343.

[12] M. Panizza, G. Cerisola, Direct and mediated anodic oxidation of organic pollutants, Chem. Rev. 109 (2009) 6541-6569. 
[13] I. Sirés, E. Brillas, Remediation of water pollution caused by pharmaceutical residues based on electrochemical separation and degradation technologies: a review, Environ. Int. 40 (2012) 212-229.

[14] I. Sirés, E. Brillas, M.A. Oturan, M.A. Rodrigo, M. Panizza, Electrochemical advanced oxidation processes: today and tomorrow. A review, Environ. Sci. Pollut. Res. 21 (2014) 8336-8367.

[15] S. Vasudevan, M.A. Oturan, Electrochemistry: as cause and cure in water pollution-an overview, Environ. Chem. Lett. 12 (2014) 97-108.

[16] I. Sirés, P.L. Cabot, F. Centellas, J.A. Garrido, R.M. Rodríguez, C. Arias, E. Brillas, Electrochemical degradation of clofibric acid in water by anodic oxidation. Comparative study with platinum and boron-doped diamond electrodes, Electrochim. Acta 52 (2006) 75-85.

[17] M. Hamza, R. Abdelhedi, E. Brillas, I. Sirés, Comparative electrochemical degradation of the triphenylmethane dye Methyl Violet with boron-doped diamond and Pt anodes, J. Electroanal. Chem. 627 (2009) 41-50.

[18] E.B. Cavalcanti, S. Garcia-Segura, F. Centellas, E. Brillas, Electrochemical incineration of omeprazole in neutral aqueous medium using a platinum or boron-doped diamond. Degradation kinetics and oxidation products, Water Res. 47 (2013) 1803-1815.

[19] L. Ciríaco, C. Anjo, J. Correia, M.J. Pacheco, A. Lopes, Electrochemical degradation of ibuprofen on $\mathrm{Ti} / \mathrm{Pt} / \mathrm{PbO}_{2}$ and $\mathrm{Si} / \mathrm{BDD}$ electrodes, Electrochim. Acta 54 (2009) 1464-1472.

[20] P. Cañizares, J. Lobato, R. Paz, M.A. Rodrigo, C. Saez, Electrochemical oxidation of phenolic compound wastes with BDD anodes, Water Res. 39 (2005) 2687-2703.

[21] E. Brillas, I. Sirés, C. Arias, P.L. Cabot, F. Centellas, R.M. Rodríguez, J.A. Garrido, Mineralization of paracetamol in aqueous medium by anodic oxidation with a boron-doped diamond electrode, Chemosphere 58 (2005) 399-406.

[22] A. Özcan, Y. Şahin, A.S. Koparal, M.A. Oturan, Propham mineralization in aqueous medium by anodic oxidation using boron-doped diamond anode. Experimental parameters' influence on degradation kinetics and mineralization efficiency, Water Res. 42 (2008) 2889-2898.

[23] V. Santos, J. Diogo, M.J.A. Pacheco, L. Ciríaco, A. Morão, A. Lopes, Electrochemical degradation of sulfonated amines on $\mathrm{Si} / \mathrm{BDD}$ electrodes, Chemosphere 79 (2010) 637-645.

[24] N. Oturan, E. Brillas, M.A. Oturan, Unprecedented total mineralization of atrazine and cyanuric acid by anodic oxidation and electro-Fenton with a boron-doped diamond anode, Environ. Chem. Lett. 10 (2012) 165-170.

[25] A. El-Ghenymy, J.A. Garrido, R.M. Rodríguez, P.L. Cabot, F. Centellas, C. Arias, E. Brillas, Degradation of sulfanilamide in acidic medium by anodic oxidation with a boron-doped diamond anode, J. Electroanal. Chem. 689 (2013) 149-157.

[26] C.I. Brinzila, N. Monterio, M.J. Pacheco, L. Ciriaco, I. Siminiceanu, A. Lopes, Degradation of tetracycline at a boron-doped diamond anode: influence of initial $\mathrm{pH}$, applied current intensity and electrolyte, Environ. Sci. Pollut. Res. 21 (2014) 8457-8465.

[27] A. Bedolla-Guzman, I. Sirés, A. Thiam, J.M. Peralta-Hernández, S Gutiérrez-Granados, E. Brillas, Application of anodic oxidation, electro-Fenton and UVA photoelectro-Fenton to decolorize and mineralize acidic solutions of Reactive Yellow 160 azo dye, Electrochim. Acta 206 (2016) 307-316.

[28] P. Cañizares, R. Paz, C. Sáez, M.A. Rodrigo, Electrochemical oxidation of alcohols and carboxylic acids with diamond anodes. A comparison with other advanced oxidation processes, Electrochim. Acta 53 (2008) 2144-2153.

[29] K. Cruz-González, O. Torres-López, A. García-León, E. Brillas, A. Hernández-Ramírez, J.M. Peralta-Hernández, Optimization of electro-Fenton/ BDD process for decolorization of a model azo dye wastewater by means of response surface methodology, Desalination 286 (2012) 63-68.

[30] A. Wang, J. Qu, H. Liu, J. Ru, Mineralization of an azo dye Acid Red 14 by photoelectro-Fenton process using an activated carbon fiber cathode, Appl. Catal. B: Environ. 84 (2008) 393-399.

[31] A. Khataee, A. Akbarpour, B. Vahi, Photoassisted electrochemical degradation of an azo dye using $\mathrm{Ti} / \mathrm{RuO}_{2}$ anode and carbon nanotubes containing gas-diffusion cathode, J. Taiwan Inst. Chem. Eng. 45 (2014) 930-936.

[32] N. Daneshvar, S. Aber, V. Vatanpour, M.H. Rasoulifard, Electro-Fenton treatment of dye solution containing Orange II: influence of operational parameters, J. Electroanal. Chem. 615 (2008) 165-174.

[33] A. Dirany, I. Sirés, N. Oturan, A. Özcan, M.A. Oturan, Electrochemical treatment of the antibiotic sulfachloropyridazine: kinetics, reaction pathways, and toxicity evolution, Environ. Sci. Technol. 46 (2012) 4074-4082.

[34] A. El-Ghenymy, R.M. Rodríguez, E. Brillas, N. Oturan, M.A. Oturan, Electro-Fenton degradation of the antibiotic sulfanilamide with $\mathrm{Pt} /$ carbon-felt and $\mathrm{BDD} /$ carbon-felt cells. Kinetics reaction intermediates, and toxicity assessment, Environ. Sci. Pollut. Res. 21 (2014) 8368-8378.

[35] M.S. Yahya, N. Oturan, K. El Kacemi, M. El Karbane, C.T. Aravindakumar, M.A. Oturan, Oxidative degradation study on antimicrobial agent ciprofloxacin by electro-Fenton process: kinetics and oxidation products, Chemosphere 117 (2014) 447-454.

[36] I. Sirés, F. Centellas, J.A. Garrido, R.M. Rodríguez, C. Arias, P.L. Cabot, E. Brillas, Mineralization of clofibric acid by electrochemical advanced oxidation processes using a boron-doped diamond anode and $\mathrm{Fe}^{2+}$ and UVA light as catalysts, Appl. Catal. B: Environ. 72 (2007) 373-381.

[37] S. Garcia-Segura, A. El-Ghenymy, F. Centellas, R.M. Rodríguez, C. Arias, J.A. Garrido, P.L. Cabot, E. Brillas, Comparative degradation of the diazo dye Direct Yellow 4 by electro-Fenton, photoelectro-Fenton and photo-assisted electro-Fenton, J. Electroanal. Chem. 681 (2012) 36-43.

[38] A. Thiam, I. Sirés, J.A. Garrido, R.M. Rodríguez, E. Brillas, Decolorization and mineralization of Allura Red AC aqueous solutions by electrochemical advanced oxidation processes, J. Hazard. Mater. 290 (2015) 34-42.

[39] A. Thiam, I. Sirés, F. Centellas, P.L. Cabot, E. Brillas, Decolorization and mineralization of Allura Red AC azo dye by solar photoelectro-Fenton: identification of intermediates, Chemosphere 136 (2015) 1-8.

[40] A.D. Eaton, L.S. Clesceri, E.W. Rice, A.E. Greenberg (Eds.), Standard Methods for the Examination of Water and Wastewater, 21 st ed., American Public Health Association (APHA), American Water Works Association (AWWA), Water Environment Federation (WEF), Washington D.C., USA, 2005.

[41] E.J. Ruiz, A. Hernández-Ramírez, J.M. Peralta-Hernández, C. Arias, E. Brillas, Application of solar photoelectro-Fenton technology to azo dyes mineralization: effect of current density, $\mathrm{Fe}^{2+}$ and dye concentrations, Chem. Eng. J. 171 (2011) 385-392.

[42] B. Boye, P.A. Michaud, B. Marselli, M.M. Dieng, E. Brillas, C. Comninellis, Anodic oxidation of 4-chlorophenoxyacetic acid on synthetic boron-doped diamond electrodes, N. Diamond Front. Carbon Technol. 12 (2002) 63-72.

[43] B. Marselli, J. Garcia-Gomez, P.A. Michaud, M.A. Rodrigo, C. Comninellis, Electrogeneration of hydroxyl radicals on boron-doped diamond electrodes, J. Electrochem. Soc. 150 (2003) D79-D83.

[44] H. Olvera-Vargas, N. Oturan, D. Buisson, M.A. Oturan, A coupled bio-EF process for mineralization of the pharmaceuticals furosemide and ranitidine: feasibility assessment, Chemosphere 155 (2016) 606-613. 